\title{
An Exploration of the Gendered Stylization of the Body in Caryl Churchill's Cloud Nine
}

\author{
Abdol Hossein Joodaki \\ Department of English Language and Literature, University of Lorestan, Khorramabad, Iran \\ E-mail: Joodaki367@yahoo.com \\ Pareia Bakhshi \\ Department of English, University of Lorestan, Khorramabad, Iran \\ E-mail: Pareiabakhshi@yahoo.com
}

Received: 08-07-2013

Accepted: 13-08-2013

Published: 01-11-2013

doi:10.7575/aiac.ijalel.v.2n.6p.98

URL: http://dx.doi.org/10.7575/aiac.ijalel.v.2n.6p.98

\begin{abstract}
What has been undertaken in the present study is the exploration of Caryl Churchill's selected drama Cloud Nine(1978) with an eye to Judith Butler's theorizations in regard to "gender performativity". According to Judith Butler, gender identity is a socio-political construction that achieves legitimacy and naturality via perpetual observation, repetition and "a stylized repetition of acts". This stylized repetition of acts along with continuous surveillance, observation and correction leads to the construction of gender identity. In Cloud Nine (1978), we witness how Caryl Churchill(1938-) , who occupies a lofty position in the world of theater due to her theatrical expertise, realizes Butler's conviction and vividly portrays the stylization of gender identity under the sovereignty and hegemony of phallocentrism and heterosexuality.
\end{abstract}

Key Words: Caryl Churchill, Judith Butler, Cloud Nine, stylization of gendered identity, surveillance, correction

\section{Introduction}

\subsection{Literary Overview}

It was in the 1980s that "theorizing about gender became the center of a new phase of critical study" and some feminists manifested a shift in focus from feminist studies to gender studies (Aston, 2000, p. 88). This newly-emerged area of study is extremely complicated for its theorists utilize "the strategies of other critical schools in their analysis of gender and sex" and have been "divided into different sub-schools that interweave the insights of disparate approaches (eg. Materialist feminists, Foucauldian theorists of gender, and psychoanalytical feminists; psychoanalytical feminists can, in turn, be divided among Freudian, Lacanian, and Kristevan thinkers)" (Felluga\&Allen, 2012). What these theorists have long pursued has, from the beginning, been emancipatory since they have tried to create "a new field of knowledge production which could gain impact on science and scholarly practices and theories" ("A Brief History of Gender Studies", 2013). One of these outstanding theorists whose seminal work Gender Trouble (1990) has been very influential in this field of study is Judith Butler who is highly indebted to such theorists and their insights as Michel Foucault (1926-1984), Julia Kristeva (1941- ), Monique Wittig (1935-2003), and Jaque Derrida (1930-2004) in the formation of her theories in regard to gender and gender studies. Judith Butler's theorizations, especially her theorizations about "gender performativity", do constitute the focal point of analysis in the analysis of Caryl Churchill's mostly acclaimed drama Cloud Nine(1978).

\subsection{Theoretical Background}

Butler's theorizations about "gender performativity" reveal that our bodies are not fundamentally and intrinsically sexed; they "become sexed through a continual process of acting and re-enacting certain gendered roles; this repetition occurs within a hegemonic system that shapes the very possibilities of the roles we can enact. If the creation of the sexed being comes from repeatedly enacting certain social norms, we may be able to knowingly disrupt the system by acting against those norms" (Oliver qtd. in Payne and Barbera, 2010, p. 270).

"Unlike what essentialists assume and unlike the popular belief in the existence of natural and innate differences between the categories of men and women, Butler considers identities as constructed within language and discourse" (Joodaki \& Bakhshi, 2013, p2). She believes that "Gender is a kind of enforced cultural performance, compelled by compulsory heterosexuality, and that, as such, it is performative" (Jagger, 2008, p. 20). As Butler has asserted, "Gender is the repeated stylization of the body, a set of repeated acts within a highly rigid regulatory frame that congeal over time to produce the appearance of substance, of a natural sort of being"(Butler, 1990, p.43).In Butler's opinion, "gender" is the fabrication of "compulsory frames" and its social appearance is incessantly policed by the various forces in order to be stylized in a specific way (Butler, p.44). Gender is thus "socially approved and politically regulated rather than dictated by some kind of internal nature"(Jagger, 2008, p. 27). 
Gender ought not to be construed as a stable identity or locus of agency from which various acts follow; rather, gender is an identity tenuously constituted in time, instituted in an exterior space through a stylized repetition of acts. The effect of gender is produced through the stylization of the body and, hence, must be understood as the mundane way in which bodily gestures, movements, and styles of various kinds constitute the illusion of an abiding gendered self(Butler, 1990, p.179).

\section{Discussion}

The stylization of the body through ceaseless policing of the social manifestation of the gender identity, according to Butler, is what the dominant "heterosexual" discourse chases and adheres to; and this stylization is what is traced in Cloud Nine by the preeminent British playwright Caryl Churchill.

In Cloud Nine(1782), Churchill's mostly staged and mostly acclaimed play, the portrayal of the characters becomes a vivid illustration of the stylization of gender identity and the socio-political regulation of the gendered being. Through "a stylized repetition of acts", gender identity (masculinity and femininity) is imposed on the individual and it is through such strategies as punishment and repetition that gender identity is fabricated, sustained and passed as something real and genuine.

Cloud Nine is composed of two acts and is considered to be the fruit of "a collective scripting process" (qtd. in Patterson, 2003, p.186) in collaboration with the Joint Stock theater Company. "The play's juxtaposition of Victorian times with the present (1979) came from the discovery in the workshop that the participants felt they had inherited Victorian traditions and ways of thinking" (Aston\& Reinelt, 2000, p.182). In order to make a parallel between the two acts and illustrate the existence and significance of the socio-political regulation and stylization of gender identity not only in Victorian England but also in the twentieth century Britain at the time of Sexual Liberation Movement, Churchill creates a 100-year time-leap forward while the characters do not age more than twenty-five years. In this outstanding drama and in the depiction of some of the characters, we also witness an abundance of instances in which gender identity is forced on individuals and individuals are urged to move within the age-old and long-established standards of propriety of gender identity. Among the characters who exemplify the stylization and the regulation of gender identity through "a stylized repetition of acts" in the drama, we can mention Edward, Betty and Cathy.

Betty's character is also the production of the "compulsory heterosexuality" and its normative instillations, through which women are tailored as submissive, "tender", 'squeamish", "irrational", "inconsistent", "treacherous, "lustful", "wicked", and" dark". The aforementioned attributes are the words of Betty's husband Clive who is the incarnation of patriarchy and its dominant discourse of mandatory heterosexuality. This stylization and regulation of the gender identity is dismantled in Betty's own remarks in the opening lines of the drama:

I live for Clive the whole aim of my life

Is to be what he looks for in a wife

I am a man's creation as you see,

And what men want is what I want to be (Churchill, 1996, p.251).

Betty's performative construction as a woman becomes more evident to us in several other scenes in which she frequently repeats not only her husband Clive but also her mother Maud:

Clive: ...we are not in this country to enjoy ourselves(Churchill, 1996, p.253).

Betty: we're not in this country to enjoy ourselves(Churchill, p.254).

Betty: The night air is deceptive. Victoria was looking pale yesterday.

Clive: My love.

[Maud comes from inside the house]

Maud: Are you warm enough Betty?

Betty: Perfectly.

Maud: The night air is deceptive(Churchill, 1996, p.256).

The fact that Betty repeats her mother's words and acts illustrates that what is regarded to be an inborn essence is just a fabrication which has achieved naturality through " a sustained set of acts" and reiteration. And according to Butler, "This repetition is at once a reenactment and reexperiencing of a set of meanings already socially established" (Butler, 1990, p.178).

Betty suffers from the monotony of life in Africa and she is fed up with her frequent waiting for Clive who is mostly out of home because of his responsibilities as Britain's supreme agent in Africa. Maud tries to remind Betty of the 
conventionally-accepted and expected behavior by stating that "you have to learn to be patient. I am patient. My mama was very patient"(Churchill, 1996, p.258), a fact which reveals the reliance of gender construction on repetition.

In the second Act of the drama, at the time of sexual liberation movement, this obedient and submissive Betty, who was a somehow paragon of the angel of the house notion turns into a different person. She easily accepts her son Edward's gayness and her daughter Victoria's lesbianism, while she was so sensitive about her children's gender propriety in the first Act of the drama and did her best to bring them up according to the accepted standards of manliness and womanliness. In the last scene of Cloud Nine, Betty even starts to talk about her early experience of masturbation in the childhood, how she had suppressed it because of the concept of taboo attached to it and how after so many years she is again doing it without that sense of regret and remorse:

I used to touch myself when I was very little, I thought I'd invented something wonderful. I used to do it to go to sleep with or to cheer myself up, and one day it was raining and I was under the kitchen table, and my mother saw me with my hand under my dress rubbing away, and she dragged me out so quickly I hit my head and it bled and I was sick, and nothing was said, and I never did it again till this year....But afterwards I thought I'd betrayed Clive. My mother would kill me. But I felt triumphant because I didn't want to be. But I don't cry about it anymore. Sometimes I do it three times in one night and it really is great fun(Churchill, p.316).

Due to a more congenial atmosphere at the time of Sexual Liberation Movement and a more feminine climate, Betty's character undergoes a drastic change and starts to become a wholly different person. She, who previously considered herself "a man's creation" in the first act of the drama, now has become a transgressive woman and contravenes the longcherished standards of propriety in the dominant discourse of phallocentrism and heterosexuality. Why Betty turns into a completely distinct person who remorselessly accepts not only her children's perversion and deviation from the longestablished norms of gender propriety but also her own divergence from those historically-sustained and approved codes of gender appropriateness.

Edward, Betty and Clive's son, who is incessantly forced by his parents to adopt and embrace standards of manliness, is the next significant character deserving attention. Clive strives hard to shape Edward's masculine gender and to secure the perpetuation of heterosexuality by frequently reminding him of manly behavior and by policing his gender acts and gestures. For instance, during one of the family gatherings, Clive allows his son Edward to drink champagne in order to shape and empower his son's masculinity according to the heterosexual norms. Clive opens the champagne:

Edward: can I have some?

Maud: Oh no Edward, not for you.

Clive: Give him half a glass.

Maud: If your father says so (Churchill, p.264)

During the same family picnic, while Clive, Harry and Edward are playing ball, Clive calls Edward with such insulting words as "butterfingers", "a baby" and "silly" when Edward misses the ball:

Clive: Butterfingers.

Edward: I am not.

Harry: Throw straight now.

Edward: I did. I did.

Clive: Keep your eye on the ball.

Clive: Don't be a baby.

Edward: I'm not, throw a hard one, throw a hard one.

Clive: Butterfingers. What will Uncle Harry think of you? (Churchill, p.265)

The offensive words Clive uses to address his son demonstrate Clive's efforts to stylize his son's gender identity according to the historically-cherished and perpetuated norms of gender propriety. If Edward wants to be accepted as an approved member in this heterosexist system, he must learn to act according to the settled standards and if he deviates a bit from those normative ideals and standards, the outcome will be quite predictable: insult, castigation, ostracization and eradication; and that is why Edward is warned by his mother Betty to hide his feminine orientation and his playing with Victoria's doll from others: "You must never let the boys at school know you like dolls. Never, never. No one will talk to you, you won't be on the cricket team, you won't grow to be a man like your papa"(Churchill, 1996, p.274). As you see, Edward is threatened and intimidated to appropriate masculinity and to "become intelligible through becoming gendered in conformity with recognizable standards of gender intelligibility"(Butler, 1990, p. 22). Elsewhere in the drama, when Edward, who is frequently seen displaying feminine traits, is slapped on the face by both Betty and Ellen because of playing with Victoria's doll, he receives the same disciplinary and regulating treatment. His mother Betty calls him "a horrid wicked boy" and threatens him with his father's upcoming corporeal punishment; and Ellen his governess threatens him that "I'm going to lock you". What is underpinned in the aforementioned instances is the fact 
that it is the combination of these constant and relentless policing and supervising activities along with corrective measures that constructs a special formation of gender identity and impedes the individual from going stray from the approved codes of manliness and womanliness. As witnessed in the drama, gender identity is not something innate; if it were an inborn feature, it would not be based on constant reiteration, policing and regulation. As Michel Foucault has stated in his Discipline and Punish, "This is the historical reality of the soul, which, unlike the soul represented by Christian theology, is not born in sin and subject to punishment, but is born rather out of methods of punishment, supervision, and constraint"(Foucault, 1991, p. 29).

In the second Act of the drama, we have another significant character Cathy through whom we can study the importance of the stylization of gender identity. Cathy's mother Lin endeavors hard to make Cathy adopt and internalize such masculine traits as violence and aggressiveness. She urges the four-year-old Cathy to toy with a toy gun and kill those children she is playing with (although imaginatively), "Don't hit him, Cathy, kill him. Point the gun, kiou, kiou, kiou. That's the way" (Churchill, 1996, p. 291). Lin also tells Victoria about her decision to buy Cathy a rifle for Christmas, "War toys. I'll give her a rifle for Christmas and blast Tommy's pretty head off for a start" (Churchill, p.292). Moreover, she abnormally encourages Cathy "to paint a car crash with blood everywhere":

Lin: Paint a house.

Cathy: No.

Lin: Princess.

Lin: Pirates.

Cathy: Already done that.

Lin: Spacemen.

Cathy: I never paint spacemen. You know I never.

Lin: Paint a car crash with blood everywhere (Churchill, p.289).

Cathy refuses to draw a house or a princess, the representations of femininity and domesticity, yet drawings such images as those of pirates, which are conventionally related to masculine sphere, engross her attention. Cathy's songs also provide us with another proof of Cathy's adoption of masculine traits because of their repletion with images of man's world such as Batman, Robin, wheel, and engine.

Based on what is delineated and observed in the drama, Cathy has been brought up unconventionally by Lin her mother to adopt and internalize masculine traits, and Lin has, to some degree, been successful in imposing masculine traits on Cathy and making her refrain from the feminine features. But what has to be taken into account here is the dramatic role the dominant sociopolitical discourse plays in the formation of individual's gender identity. Due to Cathy's unconventional and male-oriented upbringing, we see that she is frequently scolded and mocked by her schoolmates who call her a boy. The chastisement she receives from her schoolmates and their ostracization of her drives Cathy to the point of not desiring to wear jeans anymore; in spite of the fact that we already know she has always been urged by her mother not to wear frocks; this is outspokenly mentioned by Lin:

Lin [to Betty]: I've bought her three new frocks. She won't wear jeans to school anymore because Tracey and Mandy called her a boy (Churchill, 1996, p.299).

This socio-cultural regulation that first targeted Cathy is now directed towards Lin. Cathy pleads to her mom not to wear jeans in the upcoming get-together in which Tracy's mom is going to attend:

Cathy: Tracy's got a perm.

Lin: You should have shot them.

Cathy: They're coming to tea and we've got to have trifle. Not trifle you make, trifle out of a packet. And you've got to wear a skirt. And tights(Churchill, p.299).

The society's disapproval of the transgressive and unconventional way Betty and her mother dress and behave highlights the significance of the socio-cultural norms and standards in the regulation of the individual's gender identity.

\section{Conclusion}

As Butler has asserted in her preeminent work Gender Trouble (1990), "gender is an identity tenuously constituted in time, instituted in an exterior space through a stylized repetition of acts" (p.179). These stylized repetition of acts "create the illusion of an interior and organizing gender core, an illusion discursively maintained for the purposes of the regulation of sexuality within the obligatory frame of reproductive heterosexuality" ( Butler, 1990, p.139). This stylization and regulation of gender identity that occurs through perpetual surveillance, observation and correction is vividly depicted in Caryl Churchill's highly-acclaimed drama Cloud Nine. We see how those individuals who deviate from the long-rooted and long-settled standards of gender propriety are compelled to conform either through the fear of corporeal punishment or through pangs of conscience resulting from committing the historically-instilled and internalized taboos. What we notice in the drama in the characterization of the aforementioned characters is the fact that "Gender is the repeated stylization of the body, a set of repeated acts within a highly rigid regulatory frame that congeal over time to produce the appearance of substance, of a natural sort of being”(Butler, 1991, p.43). 


\section{References}

A Breif History of Gender Studies. (2013, March 7). In Linkoping University. Retrieved June 25, 2013, from http://www.tema.liu.se/tema-g/grundutb/a-brief-history-of-gender-studies?l=en

Aston, E. \& Reinelt, J. (eds). (2000). The Cambridge Companion to Modern British Women Playwrights. Cambridge: Cambridge University.

Butler, J. (1990). Gender Trouble: Feminism and the Subversion of Identity. NewYork: Routledge.

Churchill, Caryl. (1996). Plays:One. London: Methuen.

Flluga, D. \&Allen, E. (2011, January 13). General Introduction to Theories of Gender and Sex. Introductory Guide to Critical Theory. Retrieved July 10, 2012, from http:// www.cla.purude.edu.

Foucault, M. (1991). Discipline and Punish: the Birth of the Prison. United Kingdom: Penguin Books.

Jagger, G. (2008). Judith Butler: Sexual politics, Social Change and the Power of the Performative.London and New York: Routledge.

Joodaki,A, \&Bakhshi, P.(2013). The Collapse of Heterosexism and Phallogocentrism in Caryl Churchill's Cloud Nine. Studies In Literature and Language, 6(1), 127-131.

Patterson, M. (2003). Strategies of Political Theatre: Postwar British Playwrights. New York: Cambridge University Press.

Rayne, M., \& Barbera, R. J. (2010). A Dictionary of Cultural and Critical Theory. United Kingdom: Blackwell. 